\title{
Her Past: forgetting and remembering in post-Franco Spain
}

\author{
Kieran Sobels \\ University of New South Wales \\ kieran.sobels@gmail.com
}

The Spanish experience during the twentieth-century was decidedly unique due to Spain's minimal involvement in the two World Wars and its own internal political struggles. Thus, the political consensus that formed in post-Franco Spain, to forget its traumatic past and focus on the future, was facilitated by very particular circumstances. The underlying decision to impose amnesty was arguably the only viable option during the transition, but naturally bore consequences. Commentators have questioned the quality of Spanish democracy and, for many, justice was never done and thus memories never given closure. This is evident in the public demand for the rediscovery of memory since the mid-nineties. The passing of time has rendered Spain increasingly amenable to embracing transitional justice measures. While post-Franco Spain's initial approach to its traumatic past abetted a smooth and successful transition, it also served to undermine the 'democratic' institutions and political culture borne out of this period.

Indeed to understand the Spanish case, one must carefully examine the theoretical discourse on 'confronting the past' as a subject. Regime changes are decidedly complex matters and must be approached accordingly. For years, scholars, politicians and lawyers have debated how best to carry out justice while navigating the path to successful democracy. Ideally, a transition involves reconciliation through mutual forgiveness, memory and justice (Aguilar 2002, p. 17). Germany has been used as the paradigm case and purging, trials and truth commissions are generally seen as essential elements of both transitional justice and democratisation. Aguilar suggests, however, that the transitional justice path is often an impossibility (Aguilar 2002, p. 18). In certain cases, exhuming memories can have the effect of polarising societies and can only hinder the transitional process. Thus, reconciliation is often only found through amnesia. Indeed, Garton Ash has noted that democracy in Western Europe has been largely founded on the process of forgetting (Garton Ash 1998, p. 35). The Spanish case has been used to show that drawing a veil over the past can even advance the process of political democratisation (Encarnacion 2008, 
p. 436). Generally, however, scholars have sought to criticise transitions sans justice, particularly since the recent memory boom which has exposed some of Spain's shortcomings. Thus Garton Ash also problematises the issue of 'when' to confront the past, a question increasingly pertinent to post-Franco Spain (Garton Ash 1999, p. 298).

\section{The Transition and the 'Pacto del Olvido'}

The Spanish transition, after the death of Franco in 1975, is characterised by negotiation, amnesty and amnesia. It must first be noted that the Franco regime was never defeated like Nazi Germany and nor did it collapse on itself like the Soviet Union. Rather, reform began from within, as Francoist authorities decided to negotiate a regime change with the democratic opposition. Thus there was no significant rupture with the past - no purges, no trials, no truth commissions and no real attempts at justice of any kind. The Spanish case represents a prime example of an 'integrationist transition'. Eager to avoid conflict and complexities, the political left and right agreed on the 'Pacto del Olvido' (Pact of Oblivion or Forgetting). The Amnesty Law of 1977 legally imposed an amnesty and amnesia in order to suppress debate and activity regarding the Civil War and Franco's repression. Thus the Spanish decided to forget the past and focus solely on the future.

The Spanish decision to repress the past can be heavily attributed to the fact that despite Franco's death, many of his associates remained in positions of significant power. While most of the reform demands were made by the democratic opposition, the Francoist regime reformists ultimately held the upper hand in negotiations. This is primarily due to their backing by the military, the institution most closely associated with the previous regime. The military maintained significant influence as an interest group and strongly advocated regime continuity (Vilanova 1983, p156-7). Indeed, the military remained active in civic life, forcibly repressing those who spoke out against them. The resignation of newly democratic Spain's first Prime Minister Adolfo Suarez in 1981 has been attributed partly to military pressure (Vilanova 1983, p. 158). However, it was the 'Tejerazo', an attempted military coup in 1981, which most boldly highlighted the residual influence of the military. Thus the lingering existence of a powerful radical right and the military placed the democratic opposition in a position of compromise during negotiations. A radical reformist approach, let alone calling for transitional justice, was apparently out of the question, due to the fear of polarising public opinion and inciting military anger (Aguilar 2001, p. 6).

Indeed, the fear of potentially revisiting the horrors of the Civil War played a significant role in shaping the nature of the Spanish transition. While at least a generation had passed since the war and the horrors of the early repression, the memory had been transmitted and likely distilled. Further, the violence at the end of the Franco regime had vivified this memory, foregrounding the Civil War in the psyche of Spaniards during the transition (Aguilar 2001, p. 6). Accordingly, risk aversion explains the moderating of demands during the transition (Aguilar 2002, p. 151). It also meant that avoiding another Civil War was prioritised over justice and democracy (Aguilar 2001, p. 3). Thus transitional justice measures were neglected due to the fear that any measures might provoke unwanted reactions. Further, such measures would mostly be aimed at people who had already passed away. There was a general feeling that no form of justice would be adequate compensation for the 
years of suffering, so calls for transitional justice were relatively weak (Aguilar 2002, p. 191). Indeed, public demonstrations aimed at voicing discontent with the transition were actively repressed by both political parties and institutions (Aguilar 1997, p. 103-4). It was broadly considered that Spain's tendency to political 'extremism' had led it down troubled paths before, and to avoid such paths, polarisation had to be actively discouraged (McDonough, Barnes \& Pina 1998, p. 8). This desire to learn from the past meant that the failed Second Republic was used as a reference point, and democracy had to be modelled in an utterly different way (Aguilar 2002, p. 150). Democratisation would mean heralding in a new era of politics and political culture and the imposed amnesia fit in nicely with this idea.

The immediate criticism of the transition is that in privileging democratisation, the political elite neglected victims of the repression. Indeed, Davis explains that whether or not the 'Pacto del Olvido' was necessary, it perpetuated the suffering and injustice of victims of Francoism (Davis 2005, p. 867). Victims of the repression had already been kept in silence for years and thus the break with the past meant very little. In many ways the Amnesty Law continued to repress their memories, emotions and political opinions. The meagre pensions organised for republicans mutilated by war represent just one of the bones thrown to victims in a bid for political appeasement (Aguilar 2001, p. 25). Amnesty for victims of the repression was insultingly insufficient. However, it must be questioned whether any measure of transitional justice would have been adequate.

Continuities between the old and new regimes also bring into question the effectiveness of democratisation in Spain. While attempting to refute authoritarianism, the new 'democratic' regime continued to practice it itself. As shown above, the Amnesty Law itself represented an infringement on democracy and liberalism. Police forces maintained an authoritarian style for many years, often suppressing socio-political movements and brutally demobilising public demonstrations (Aguilar 1997, p. 103-4). In addition, the military remained everpresent in civic life. Indeed, the violence of the transition is often ignored in favour of a rosy, peaceful image of history. In fact, between 1975 and 1980 there were 460 violent political deaths, 400 deaths as a result of political terrorism and 63 deaths in street demonstration (Aguilar 2001, p. 5). Institutions of the Franco era were not dismantled and often hardly reformed. Francoist party members were even maintained in positions of power in many administration bodies. Thus democracy was taking root at a very slow pace, and arguably growing into something of an inferior quality.

Indeed, the lack of reform and retroactive justice has regularly been blamed for creating a democracy that is institutionally well established, but lacking in depth. Spain has been described as something of a "democracy lite" (McDonough, Barnes \& Pina 1998, p. 1). The argument is not unfamiliar. Authoritarianism not only lingered in practice, but in political culture. Franco retained supporters well into the 1980 s and many saw positive aspects in his regime (Aguilar \& Humlebaek 2002, p. 130). In fact, in 2000 only 37.4 per cent called the Franco regime a "negative period" in Spanish history (Aguilar \& Humlebaek 2002, p. 131). This is a direct result of the failure to denounce Franco and authoritarianism during the transition. Buck and Colomer have both noted the successes of Spanish democratisation, but have argued the process has produced something mediocre - "stable, but limited", lacking transparency and truly democratic decision making (Buck 1998 \& Colomer 1998). 
Most authors, however, feel that attempts at institutional democratisation were relatively successful, particularly given the circumstances. On the other hand, culturally, democratisation has been less complete. The repression of pluralism and public political participation during both the Franco regime and the transition have fostered an apathetic attitude to politics in Spain (Magone 2009, p. 39). The failure of Spain's democratisation is thus the failure to encourage a strong, democratic civic society.

Another problematic legacy of the transition has been the attitude towards national identity. National identity in Spain continues to be haunted by negative connotations attached to Spanish nationalism or patriotism (Aguilar \& Humlebaek 2002, p. 122). This is due to the manufactured concepts of nation and patriotism under Franco, which have now come to be naturally associated with the repression. The issue is only compounded by the pluralism of regional identities in Spain. The awkward nature of the national identity must be blamed on a failure to foster nationalism distinctly representing democratic Spain (Aguilar \& Humlebaek 2002, p. 155). Rather than creating new foundational symbols, Spain retained its most significant former symbols - the national holiday, the national anthem and the flag. Further, minimal attempts were made to remove Francoist symbolism in the public sphere. National identity thus represents but another problematic continuity with the Franco regime, a direct result of the consensus to 'forget' and essentially refuse to deal with the past.

The decisions made during the transition must be framed contextually and given the lack of apparent politically viable alternatives, the 'Pacto del Olvido' should at least be defended as an effective determination. Encarnacion calls for scholars to recognise the "local realities" of the Spanish situation (Encarnacion 2008, p. 456). Indeed the residual power of the authoritarian rule and the very real fear of another civil war are among a broader set of socio-economic and political factors that virtually forced Spain into taking an integrationist approach to transition. Perhaps rather than questioning if the Spanish 'should' have acted differently, it should be asked if they 'could' have acted differently. Aguilar suggests that "viable political alternatives" did not exist and praises the compromising approach of the opposition, which avoided the outbreak of significant political violence (Aguilar 2001, p. 6, 18). Indeed, while drawing a veil over the past had it consequences, the course taken by the political elite did ultimately achieve its goal in guiding Spain on the path to democracy.

\section{The Recovery of Memory}

It was only after democracy had apparently solidified and fears had passed that public demand emerged for the recovery of memory. A number of domestic and international contextual changes had taken place, allowing for the silence to be broken. Most notable of all, time had passed and Spain's democracy and political culture had matured. By the mid-nineties a strong right had formed in the People's Party, which would be elected to government in 1996. This represented a key date in Spain's growth as a democratic nation (Davis 2005, p. 870). Further, new issues could be raised without political backlash (Davis 2005, p. 870). Garcia de Andoin of the Socialist party voiced this belief, stating that "during the transition, looking at the past meant opening old divisions" but now it is "no threat to the stability of the state" (de Andoin quoted in Encarnacion 2008, p. 447). 
Resurgent interest in the past can be primarily attributed to a chain of events beginning with the Pinochet affair. In 1998, Spanish judge Baltasar Garzon issued an international arrest warrant for Chilean dictator Augusto Pinochet on the basis of crimes against humanity. Spanish society pursued and supported the case with considerable fervour, which led to international accusations of moral hypocrisy (Davis 2005, p. 868). Naturally, the affair provided the spark needed in Spanish society to ignite interest in its own past. The emergence of global human rights groups and a trend in advocating truth commissions provided further external pressure (Golob 2008, p. 127). Public demand in Spain grew in relation to truth and justice concerning the atrocities of the Civil War and the repression. By 2000 this had culminated in the founding of the Association for Recovery of Historical Memory, an organisation dedicated primarily to investigating and bringing justice to the victims of the Franco regime. The ARMH has proven pivotal in mobilising the public sphere and drawing political attention. Indeed, despite the nest efforts of the government in ignoring public demands, the movement soon also gained political support from the Socialist Party and the political left.

Political attention culminated in the Law of Historical Memory, 2007, passed by the Zapatero government, which represented a symbolic step in confronting Spain's past. The law sought to recognise and expand on victims' rights, promote "personal and family memory" and eradicate the material legacy of Franco (Encarnacion 2008, p. 452). The law has been criticised by both the left, arguing a case of 'too little, too late', and the right, arguing it serves no practical political purpose (Golob 2008, p. 136). Indeed, on a practical level the law has achieved little in terms of retroactive justice. Critics have pointed to numerous shortcomings, including the failure to declare rulings from the Franco era void (Blakely 2012, p. 10). A lack of consensus still defines whether and how the Franco regime and its victims should be recognised (Golob 2008, p. 136). Blakely argues, however, that the law's strength lies in its symbolic effect and that it should be viewed as a foundation upon which further initiatives can be taken in dealing with Spain's past (Blakely 2012, p. 10). The law is representative of the first major step in ensuring moral compensation for Franco's victims, an element so often seen as essential in confronting a nation's troubled past (Aguilar 2008, p. 430). While this reparation law has been fairly criticised as inadequate, it is open-ended and thus paves the way for further measures. Spain is clearly still dealing with its past.

\section{Concluding Evaluation}

Spain's reputation as a model for transition is problematic, as certain approaches work in different contexts and situations. Traditionally the Spanish transition has been widely praised for guiding a politically cursed nation to established democracy. Wiarda calls Spain one of the "great success stories of modernisation" (Wiarda 2000, p. 31). However, it is hard to tell if decisions during the transition are directly responsible for this success. After all, the Franco regime had already begun to reinvent itself through socio-economic reform. Aguilar has pointed out that it could be simply that the economic, social and political context were much more favourable to the rise of democracy than ever before (Aguilar 2002, p. 162). The case of Poland after communism particularly lays bare the flaws of the Spanish approach. The new Mazowiecki government's "thick line under the past" drew heavily on the Spanish experience as inspiration. While the Polish transition was negotiated, however, the 
circumstances were decidedly particular, with the outgoing regime enjoying less of a power position. The memory of the Spanish Civil War must also not go undervalued. Poland's price for not practising political purging led to recurring 'mud-slinging' and a problematic political sphere (Garton Ash 1999, p. 306). The rupture in the 'Pacto del Olvido' during the nineties also exposed the shortcomings of amnesty and amnesia (Davis 2005, p. 880).

Undoubtedly the Spanish transition had its negative implications, the most notable of which being the focus on institutional democratisation over cultural democratisation, but one cannot lay the blame solely on the political consensus during the transition. Firstly it is questionable as to whether alternatives existed. Secondly it is just as flawed hypothetically applying other models to the Spanish case, as it is applying the Spanish model to other cases. It is unlikely truth commissions or purging would have achieved anything in furthering democracy (Encarnacion 2008, p. 457). Spain has also recognised its faults and has recently made attempts at consolidating democracy on a cultural level, moving beyond "political conciliation" to a "broader social conciliation" (Blakely 2005, p. 44). With the benefit of hindsight one may say such developments could have happened earlier, but most importantly Spain is still consolidating its democracy and beginning to confront the past.

Post-Franco Spain's approach in dealing with the past represents the best efforts of politicians in attempting to foster a democracy in a troubled socio-political context. Indeed, when the trauma of Spain's past and its broader political history is taken into account, Spain's transition must be considered a success. Steps in more recent years aimed at recovering memory, however, show that Spain acknowledges the shortcomings of the transition. Undoubtedly more can be done to bring justice to the memories and victims of the Franco past, and in turn improve Spanish democratic culture, but it must also be recognised that whatever steps are taken, the past can never be completely mastered.

\section{Bibliography}

Aguilar, P 1997, 'Collective memory of the Spanish civil war: The case of the political amnesty in the Spanish transition to democracy’, Democratization, vol. 4, no. 4, pp 88-109.

Aguilar, P 2001, 'Justice Politics and Memory in the Spanish Transition', in AB De Brito, C GonzalezEnriquez \& P Aguilar (eds) The Politics of Memory and Democratization: Transitional Justice in Democratizing Societies, Oxford University Press, Oxford, pp 92-118.

Aguilar, P 2002, Memory and Amnesia: The Role of the Spanish Civil War in the Transition to Democracy, Berghahn Books, New York.

Aguilar, P 2008, 'Transitional or Post-transitional Justice? Recent Developments in the Spanish Case', South European Society and Politics, vol. 13, no. 4, pp 417-433.

Aguilar, P \& Humlebaek, C 2002, 'Collective Memory and National Identity in the Spanish Democracy: The Legacies of Francoism and the Civil War', History and Memory, vol. 14, no. 1-2, pp 121-164.

Blakeley, G 2005, 'Digging up Spain's past: consequences of truth and reconciliation', Democratization, vol. 12, no. 1, pp 44-59. 
Blakeley, G 2012, 'Evaluating Spain's Reparation Law', Democratization, iFirst, accessed 10 October 2012 <<http://www.tandfonline.com/doi/pdf/10.1080/13510347.2011.650912>>.

Buck, M 1998. 'The Exemplary Transition from Authoritarianism: Some Notes on the Legacy of Undemocratic Decision-making in Spain', in SU Larsen (ed.) Modern Europe after Fascism, 19431980s, Social Science, Boulder, pp 1607-1635.

Colomer, JM 1998, La transición a la democracia: el modelo español, Anagrama, Barcelona.

Davis, M 2005, 'Is Spain Recovering its Memory? Breaking the Pacto del Olvido', Human Rights Quarterly, vol. 27, no. 3, pp 858-880.

Encarnacion, O G 2008, 'Reconciliation after Democratization: Coping with the Past in Spain', Political Science Quaterly, vol 123, no. 3, pp 435-470.

Garton Ash, T 1998, 'The Truth About Dictatorship', The New York Review of Books, vol 45, no. 3, pp $35-40$.

Garton Ash, T 1999, 'Trials, Purges and History Lessons', in T Garton Ash (ed.) History of the Present: Essays, Sketches and Despatches from Europe in the 1990s, Penguin, London, pp 294-314.

Golob, SR 2008, 'Volver: The Return of/to Transitional Justice Politics in Spain', Journal of Spanish Cultural Studies, vol. 9, no. 2, pp 127-141.

Magone, J M 2009, Contemporary Spanish Politics, 2nd edn, Routledge, New York.

McDonough, P, Barnes, S H \& Pina, A L 1998, The Cultural Dynamics of Democratization in Spain, Cornell University Press, Ithaca.

Vilanova, P 1983, 'Spain: The Army and the Transition' in D S Bell (ed.) Democratic Politics in Spain, Frances Pinter, London, pp 147-164.

Wiarda, H J 2000, 'Spain 2000: A Normal Country?', Mediterranean Quarterly, vol. 11, no. 3, pp 3061. 